\title{
PENGARUH MODEL PEMBELAJARAN STAD TERHADAP HASIL BELAJAR MATA PELAJARAN AKUNTANSI
}

\author{
${ }^{1}$ Muhamad Yasir \\ ${ }^{2}$ Elin Karlina \\ ${ }^{1}$ Guru SMK Nasyrul Ulum Pandeglang, Banten \\ ${ }^{2}$ Dosen Program Studi Pendidikan Ekonomi Universitas Indraprasta PGRI \\ e-mail : yasir11acil@gmail.com \\ elinkarlina27@yahoo.com
}

\begin{abstract}
Abstrak
Penelitian ini dilaksanakan untuk mengetahui tentang Pengaruh Model Pembelajaran Student Teams Achievement Division (STAD) terhadap Hasil Belajar Mata Pelajaran Akuntansi di Sekolah Menengah Kejuruan (SMK) Nasyrul Ulum Pandeglang, Banten. Metode penelitian yang digunakan dalam penelitian ini adalah metode eksperimen. Dalam pelaksanaan penelitian ini melibatkan dua kelompok, yaitu kelompok eksperimen yang diberi perlakuan dengan menggunakan model pembelajaran tipe STAD, dan kelompok kontrol yang diberikan perlakuan dengan model pembelajaran ceramah. Hasil penelitian menunjukkan bahwa hasil belajar yang menggunakanmodel pembelajran Student Teams Achievement Division (STAD) lebih tinggi dari hasil belajar yang menggunakan pembelajaran ceramah atau dengan kata lain bahwa pemberian model pembelajaran Student Teams Achievement Division (STAD) berpengaruh terhadap hasil belajar akuntansi peserta didik.
\end{abstract}

Kata kunci : model pembelajaran Student Teams Achievement Division (STAD), model pembelajaran ceramah, Hasil Belajar Akuntansi.

\section{PENDAHULUAN}

Bagi orang-orang yang berkompeten dan peduli terhadap bidang pendidikanakan menyadari bahwa dunia pendidikan kita sampai saat ini semakin hari semakin rendah. Dunia pendidikan yang rendah ini disebabkan karena pendidikan yang seharusnya membuat manusia menjadi manusia, tetapi dalam kenyataannya seringkali tidak seperti itu. Seringkali pendidikan tidak memanusiakan manusia. Kepribadian manusia cenderung direduksi oleh sistem pendidikan yang ada, serta kurang seimbang antara belajar yang berpikir (kognitif) dan perilaku belajar yang merasa (afektif). Jadi unsur integrasi cenderung semakin hilang, yang terjadi karena disintegrasi.

Sebenarnya belajar tidak hanya berpikir saja, Sebab ketika orang sedang belajar, maka orang yang sedang belajar tersebut melakukan berbagai macam kegiatan, seperti mengamati, membandingkan, meragukan, menyukai, semangat dan sebagainya. Hal yang sering disinyalir ialah pendidikan seringkali dipraktekkan sebagai sederetan instruksi dari guru kepada siswa. Kenyataan ini nampaknya justru disambut dengan antusias oleh banyak lembaga pendidikan.Jadi hubungannya itu guru sebagai subyek dan murid sebagai obyek.

Model pendidikan ini tidak membebaskan karena sangat menindas para peserta didik. Dari model pendidikan yang demikian maka manusia yang dihasilkan pendidikan ini hanya siap untuk memenuhi kebutuhan zaman dan bukannya bersikap kritis terhadap 
zamannya. Melainkan justru hendak mengajak kita semua untuk melihat kenyataan ini sebagai sebuah tantangan bagi dunia pendidikan kita. Mampukah kita menjadikan lembaga pendidikan sebagai sarana interaksi kultural untuk membentuk manusia yang sadar akan tradisi dan kebudayaan serta keberadaan masyarakatnya sekaligus juga mampu menerima dan menghargai keberadaan tradisi, budaya dan situasi masyarakat lain.

Dalam permasalahan tersebut berarti bahwa berhasil tidaknya pencapaian tujuan pendidikan banyak tergantung kepada pendidik dalam memilih model pembelajaran, bagaimana caranya supaya pendidik dapat memberikan model pembelajaran yang memotivasi para peserta didik agar semangat dalam belajar. Setiap guru pasti setuju akan pentingnya penggunaan metode, apalagi dengan menggunakan metode yang bervariasi pasti akan banyak disukai oleh peserta didik. Oleh karena itu, pemilihan berbagai metode, strategi, pendekatan serta teknik pembelajaran merupakan suatu hal pokok

Dalam permasalahan tersebut banyak metode yang dilakukan oleh para pendidik untuk meningkatkan proses belajar mata pelajaran akuntansi siswa, salah satunya dengan menggunakan metode Student Teams Achievement Division (STAD), metode ini merupakan salah satu metode atau pendekatan dalam pembelajaran kooperatif yang sederhana dan baik, apalagi untuk guru yang baru mulai menggunakan pendekatan kooperatif dalam kelas. Student Teams Achievement Division STAD juga merupakan suatu metode pembelajaran kooperatif yang efektif. Model pembelajaran itu dikatakan efektif bila menghasilkan sesuatu sesuai dengan yang diharapkan atau dengan kata lain tujuan tercapai yaitu dapat meningkatkan hasil belajar peserta didik. Sedangkan model mengajar dikatakan efisien bila penerapannya dalam menghasilkan sesuatu yang diharapkan itu relatif menggunakan tenaga, usaha, pengeluaran, biaya, dan waktu minimum.

\section{TINJAUAN PUSTAKA}

\section{Hasil Belajar Akuntansi}

Bagi seorang siswa, belajar merupakan suatu kewajiban. Berhasil atau tidaknya seorang siswa dalam pendidikan tergantung pada proses belajar yang dialami oleh siswa tersebut.Di dalam belajar, siswa mengalami sendiri proses dari tidak tahu menjadi tahu, dari tidak mengerti menjadi mengerti, dan dari yang tidak memahami menjadi memahami.

Menurut Aunurrahman (2010:35) mengemukakan bahwa, "belajar adalah suatu proses yang dilakukan individu untuk memperoleh suatu perubahan tingkah laku yang baru secara keseluruhan, sebagai hasil pengalaman individu itu sendiri di dalam interaksi dengan lingkungannya".

Dengan demikian bahwa belajar itu suatu perubaahan tingkah laku dimana seseorang belajar yang sudah belajar akan mendapatkan suatu pengetahuan dimana pengetahuan itu salah satunya bisa merubah tingkah laku siswa seperti nilai-nilai, norma, dan pengetahuan-pengetahuan lainnya.

Dalam aktivitas kehidupan sehari-hari hampir tidak pernah dapat terlepas dari kegiatan belajar, baik ketika seseorang melaksanakan aktivitas sendiri, maupun dalam suatu kelompok tertentu. Dengan demikian dapat dikatakan, manusia tidak dapat melepaskan dirinya dari kegiatan belajar, dan itu berarti pula bahwa belajar tidak pernah di batasi usia, tempat maupun waktu, karena perubahan yang menuntut terjadinya aktivitas belajar itu juga tidak pernah berhenti. Oleh karena itu, pemahaman yang benar 
mengenai arti belajar dengan segala aspek, bentuk dan manifestasinya diperlukan oleh para pendidik.

Menurut Hamalik (2008:36) mengatakan bahwa: "belajar adalah merupakan suatu proses, suatu kegiatan dan bukan suatu hasil atau tujuan".Belajar bukan hanya mengingat, namun melainkan perubahan kelakuan. Oleh karena itu bahwa belajar suatu kegiatan dimana seseorang mempelajari suatu hal yang dapat memberikan suatu informasi atau pengalaman. Dengan kata lain belajar ialah menujukan suatu aktivitas pada diri seseorang yang didasari atau disengaja.

Dalam melakukan kegiatan belajar, terjadi proses berpikir yang melibatkan kegiatan mental, terjadi penyusunan hubungan informasi-informasi yang diterima sehingga timbul suatu pemahaman dan penguasaan terhadap materi yang diberikan. Pemahaman dan penguasaan ini disebut sebagai hasil belajar.

Menurut Amaliah (2012:39) mengatakan bahwa: "hasil belajar adalah ketercapaian setiap kemampuan dasar, baik kognitif, afektif maupun psikomotorik, yang diperoleh peserta didik selama mengikuti kegiatan pembelajaran tertentu".

Hasil belajar dapat diperoleh ketika siswa sudah mengikuti pembelajaran dan setelah itu guru memberikan tugas-tugas kepada siswa untuk melihat hasil belajar yang selama pembelajaran berlangsung, selain itu guru memotivasi siswa agar selalu giat dalam belajar. Pada hakikatnya hasil belajar adalah perubahan tingkah laku yang diharapkan pada diri siswa setelah mengalami proses belajar mengajar.

Menurut Benyamin S. Bloom, dkk. (dalam Amaliah, 2012: 21), "hasil belajar dapat dikelompokan kedalam tiga domain, yaitu kognitif, afektif dan psikomotor".Ranah kognitif merupakan tujuan pendidikan yang sifatnya menambahkan pengetahuan atau hasil belajar seperti pengetahuan atau ingatan, pemahaman, aplikasi (penerapan), analisis, sistematis, dan evaluasi. Ranah afektif merupakan tujuan pendidikan yang sifatnya menambah kemampuan atau hasil belajar yang berhubungan dengan sikap, yang terdiri dari aspek penerimaan, partisipasi, penilaian, organisasi. Sedangkan ranah psikomotor merupakan tujuan pendidikan yang sifatnya menambah pengetahuan atau hasil belajar yang berhubungan dengan keterampilan atau keaktifan fisik (motor skill), yang terdiri dari aspek observasi, imitasi, pembiasaan dan penyesuaian.

Jadi ketiga ranah tersebut menjadi objek penilaian hasil belajar yang mana dari ketiga ranah tersebut ranah kognitiflah yang paling banyak dinilai oleh para guru di sekolah karena berkaitan dengan kemampuan siswa dalam menguasai isi bahan pelajaran. Taksonomi atau penggolongan tujuan ranah kognitif oleh Bloom, mengemukakan adanya 6 (enam) kelas/tingkat yaitu pengetahuan, pemahaman, penerapan (aplikasi), analisis, sintesis dan evaluasi.

Pengetahuan merupakan tingkat rendah tujuan ranah kognitif berupa pengalaman dan pengingatan kembali terhadap pengetahuan tentang fakta, istilah dan prinsip-prinsip dalam bentuk seperti yang dipelajari. Namun tipe hasil belajar ini menjadi persyaratan bagi tipe hasil belajar yang berikutnya.

Perkembangan akuntansi sejalan dengan perkembangan dunia usaha dan dunia pendidikan. Maksudnya dalam dunia pendidikan akan memberikan pembaharuan seperti Kurikulum, buku-buku, LKS yang digunakan oleh guru bidang studi, materi yang diajarkan yang oleh guru dalam mata pelajaran akuntansi ini akan selalu ada kaitannya dengan membandingkan antara jumlah harta, nilai nominal dan pembuatan Laporan Laba/rugi. Dalam dunia usaha akuntansi itu akan selalu berkaitan dengan jumlah harta, dana awal dan hasil sisa usaha. 
Proses pembelajaran mata pelajaran akuntansi di sekolah dikatakan berhasil jika siswa dapat belajar secara optimal dan mendapatkan hasil yang baik selain itu tercapainya tujuan pembelajaran yang telah ditentukan oleh guru. Hasil belajar mata pelajaran akuntansi yang akan peneliti gunakan yaitu pada ranah kognitif karena berkenaan dengan hasil belajar intelektual yang terdiri dari enam aspek yaitu pengetahuan atau ingatan, pemahaman, aplikasi, analisis, sintesis dan evaluasi. Berikut tersajikan hasil belajar mata pelajaran akuntansi dengan silabus dan termasuk dengan ranah-ranah sebagai berikut:

Tabel 1. Kaitan Antara Kegiatan Pembelajaran Dengan Domain Tingkatan Ranah Kognitif

\section{Indikator}

1. Dapat menyediakan peralatan yang diperlukan untuk pengelolaan buku besar

2. Dapat menyediakan sumber data akuntansi dan format-format yang diperlukan untuk pengelolaan buku besar

1. Dapat meyebutkan pengertian buku besar dalam proses akuntansi

2. Dapat meyebutkan jenis-jenis format buku besar yang sering digunakan oleh perusahaan

3. Dapat meyebutkan pedoman sistem penomoran buku besar suatu perusahaan

4. Dapat meyebutkan kegunaan dari rekapitulasi jurnal

5. Dapat menguraikan 6 kelompok besar untuk buku besar

6. Dapat mengidentifikasi akun-akun yang terkait dengan rekapitulas

1. Dapat mengikuti prosedur pembukuan (posting) ke buku besar dengan SOP perusahaan

2. Dapat membukukan (posting) jumlah-jumlah yang ada dalam rekapitulasi jurnal dalam buku besar

1. Dapat menentukan bahwa prosedur posting buku besar pada perusahaan jasa dan prosedur posting pada perusahaan dagang adalah sama

1. Dapat menyebutkan saldo normal untuk setiap kelompok akun buku besar

2. Dapat menyusun neraca saldo

1. Dapat menunjukan ciri-ciri yang ada dalam neraca saldo bahwa saldo-saldo akun buku besar yang dibukukab adalah benar

2. Dapat menentukan bahwa apabila total debet dan total kredit dalam neraca saldo sama besar
Ranah

C3. Penerapan

C1. Pengetahuan

C3. Penerapan

C2. Pemahaman

C1. Pengetahuan

C2. Pemahaman

\section{Modelpembelajaran Student Teams Achievement Division (STAD)}

Kegiatan pembelajaran yang diselenggarakan oleh setiap guru, selalu bermula dari dan pada komponen-komponen pembelajaran yang tersurat dari kurikulum. Oleh sebab itu pembelajaran yang diselenggarakan oleh guru merupakan bagian utama dari pendidikan formal yang syarat mutlaknya adalah adanya kurikulum sebagai pedoman. Dengan demikian, guru dalam merancang program pembelajaran maupun pelaksanaan proses pembelajaran akan selalu berpedoman pada kurikulum.

Pengertian model pembelajaran Menurut Joyce (dalam, Trianto, 2011:5) mengemukakan bahwa, "Model pembelajaran adalah suatu perencanaan atau suatu pola yang digunakan sebagai pedoman dalam merencanakan pembelajaran di kelas atau 
pembelajaran dalam tutorial dan untuk menentukan perangkat-perangkat pembelajaran termasuk di dalamnya buku-buku, film, komputer, kurikullum dan lain-lain".

Sedangkan menurut La Iru (2012:4),"model pembelajaran adalahcara kerja yang bersistem untuk memudahkan pelaksanaan pembelajaran sehingga kompetensi dan tujuan pembelajaran dapat tercapai".

Pendekatan siswa aktif memandang pembelajaran akan terjadi apabila siswa terlibat dalam pembelajaran, guru hendaknya mengembangkan pembelajaran yang memungkinkan dapat dijadikan wahana bagi siswa untuk terlibat aktif dalam memahami berbagai kompleksitas problem pembelajaran.

Pembelajaran kooperatif bukanlah sesuatu yang baru, pembelajaran ini bersifat konstruktivistik, dimana siswa secara aktif memperoleh pengetahuan baru, dan guru hanya sebagai fasilitator. Pembelajaran ini muncul dari konsep bahwa siswa akan lebih mudah menemukan dan memahami konsep yang sulit jika mereka berdiskusi dengan temannya.

Tentang pengertian pembelajaran kooperatif, Menurut Airihi (dalam, La Iru 2012:47) mengemukakan bahwa, "Pembelajaran kooperatif adalah merupakan model pembelajaran dalam kelompok-kelompok kecil dengan anggota kelompok 3-5 orang, yang dalam menyelesaikan tugas kelompoknya setiap anggota kelompok harus saling kerja sama dan saling membantu untuk memahami materi, sehingga setiap siswa selain mempunyai tanggung jawab individu, tanggung jawab berpasangan, juga mempunyai tanggung jawab dalam kelompok".

Jadi setiap siswa mempunyai tanggung jawab sendiri meskipun dalam bentuk kelompok, metode ini mengajarkan kepada siswa dalam berinteraksi antar siswa untuk menyelesaikan tugas yang disampaikan oleh guru dan juga siswa mempunyai tugas individu sehingga siswa dalam satu kelompok itu tidak ada lagi siswa yang hanya duduk dan hanya mengandalkan temannya yang lain.

Sistem penilaian dilakukan terhadap kelompok. Setiap kelompok akan memperoleh penghargaan, jika kelompok mampu menunjukkan prestasi yang di persyaratkan. Dengan demikian, setiap anggota kelompok akan mempunyai ketergantungan positif. Ketergantungan semacam itulah yang selanjutnya akan memunculkan tanggung jawab individu terhadap kelompok dan keterampilan interpersonal dari setiap anggota kelompok. Setiap individu akan saling membantu, mereka akan mempunyai motivasi untuk keberhasilan kelompok, sehingga setiap individu akan memiliki kesempatan yang sama untuk memberikan kontribusi demi keberhasilan kelompok.

Pembelajaran kooperatif tipe STAD ini merupakan salah satu tipe dari model pembelajaran kooperatif dengan menggunakan kelompok-kelompok kecil dengan jumlah kelompok terdiri dari 4-5 orang siswa secara heterogen. Diawali penyampaian tujuan pembelajaran, penyampaian materi, kegiatan kelompok, kuis, dan penghargaan kelompok.

Menurut Trianto (2011:52) menyatakan bahwa, "Pembelajaran kooperatif tipe STAD adalah merupakan salah satu tipe dari model pembelajaran kooperatif dengan menggunakan kelompok-kelompok kecil dengan jumlah anggota tiap anggota tiap kelompok 4-5 orang siswa secara heterogen".

Maksudnya guru menyajikan pelajaran, dan kemudian siswa bekerja dalam tim mereka memastikan bahwa seluruh anggota tim telah menguasai pelajaran tersebut. Kemudian, seluruh siswa diberikan tes tentang materi tersebut, pada saat tes ini mereka tidak diperbolehkan saling membantu. Dengan kata lain dapat digunakan untuk 
memberikan pemahaman konsep materi yang sulit kepada siswa dimana materi tersebut telah dipersiapkan oleh guru melalui lembar kerja atau perangkat pembelajaran yang lain. Langkah-langkah model pembelajaran Kooperatif Tipe Student Teams Achievement Division (STAD) terdiri atas enam langkah yaitu:

1. Menyampaikan tujuan dan memotivasi siswa

Guru menyampaikan semua tujuan pembelajaran yang ingin dicapai pada pembelajaran tersebut dan memotivasi siswa belajar.

2. Menyajikan/ menyampaikan informasi

Menyajikan informasi kepada siswa dengan jalan mendemonstrasikan atau lewat bahan bacaan.

3. Mengorganisasikan siswa dalam kelompok-kelompok belajar.

Menjelaskan kepada siswa bagaimana caranya membentuk kelompok belajar dan membentuk setiap kelompok agar melakukan transisi secara efesien.

4. Membimbing kelompok bekerja dan belajar

5. Membimbing kelompok-kelompok belajar pada saat mereka mengerjakan tugas mereka.

6. Evaluasi

Mengevaluasi hasil belajar tentang materi yang telah diajarkan atau masing-masing kelompok mempresentasikan hasil kerjanya.

7. Memberikan penghargaan

Mencari cara-cara untuk menghargai baik upaya maupun hasil belajar individu dan kelompoknya.

Penghargaan atas keberhasilan kelompok dapat dilakukan oleh guru dengan melakukan tahapan-tahapan sebagai berikut:

a. Menghitung skor individu

Menurut Slavin (dalam La Iru, 2012: 58), untuk memberikan skor perkembangan individu dihitung seperti pada:

Tabel 2.Perhitungan Skor Perkembangan

\begin{tabular}{lc}
\multicolumn{1}{c}{ Nilai Tes } & $\begin{array}{c}\text { Skor } \\
\text { Perkembangan }\end{array}$ \\
\hline Lebih dari 10 poin di bawah skor awal & 0 \\
10 poin di bawah sampai 1h skor awal poin di bawah & 10 \\
skor awal & 20 \\
Skor awal sampai 10 poin di atas skor awal & 30 \\
Lebih dari 10 poin di atas skor awal & 30 \\
Nilai Sempurna (tanpa memperhatihan skor awal) & \\
\hline
\end{tabular}

b. Menghitung skor kelompok

Untuk menghitung skor kelompok, dihitung dengan rata-rata skor perkembangan anggota kelompok. Menurut Ratumanan (dalam Trianto,2011:56) mengatakan sesuai dengan rata-rata skor perkembangan kelompok, diperoleh kategori skor seperti tercantum pada tabel berikut: 
Tabel 3. Tingkat Penghargaan Kelompok

\begin{tabular}{cc} 
Rata-rata tim & Predikat \\
\hline $\mathbf{0} \leq \boldsymbol{x} \leq \mathbf{5}$ & - \\
$\mathbf{5} \leq \boldsymbol{x} \leq \mathbf{1 5}$ & Tim Baik \\
$\mathbf{1 5} \leq \boldsymbol{x} \leq \mathbf{2 5}$ & Tim Sangat Baik \\
$\mathbf{2 5} \leq \boldsymbol{x} \leq \mathbf{3 0}$ & Tim Super \\
\hline
\end{tabular}

c. Pemberian penghargaan dan pengakuan skor kelompok

Menurut Dayanti (2011:46) menyatakan bahwa: "Penghargaan dari guru berupa nilai, sertifikat atau bingkisan hadiah yang diumumkan sesudah proses belajar mengajar selesai, sehingga siswa termotivasi”. Pemberian penghargaan ini berdasarkan predikat yang didapatkan oleh kelompok.

Adapun kelebihan pendekatan model pembelajaran Kooperatif Tipe Student Teams Achievement Division (STAD), antara lain:

1. Meningkatkan kecakapan individu.

2. Meningkatkan kecakapan kelompok.

3. Meningkatkan komitmen, percaya diri.

4. Menghilangkan prasangka terhadap teman sebaya dan memahami perbedaan.

5. Tidak bersifat kompetitif.

6. Tidak memiliki rasa dendam dan mampu membina hubungan yang hangat.

7. Meningkatkan motivasi belajar dan rasa toleransi serta saling membantu dan mendukung dalam memecahkan masalah.

Di samping kelebihan pendekatan model pembelajaran Kooperatif Tipe Student Teams Achievement Division (STAD), juga terdapat kekurangan pendekatan model pembelajaran Kooperatif Tipe Student Teams Achievement Division (STAD), yaitu:

1. Siswa yang kurang pandai dan kurang rajin akan merasa minder berkerja sama dengan teman-teman yang lebih mampu.

2. Terjadi situasi kelas yang gaduh singga siswa tidak dapat bekerja secara efektif dalam kelompok.

3. Pemborosan waktu.

\section{Model pembelajaran ceramah}

Model pembelajaran konvensional ini salah satu model pembelajaran jaman dulu sampai sekarang masih berlaku dan sangat banyak digunakan oleh guru. Karena model konvensional ini suatu metode yang paling sederhana yang digunakan oleh dewan guru dan dalam proses belajar mengajar motode ini sama dengan metode ceramah yang biasa digunakan oleh dewan guru jaman dulu, dengan kata lain metode ceramah ini suatu cara yang paling mudah dalam menyampaikan materi kepada peserta didik karena dalam proses belajar mengajarnya hanya menjelaskan, memberitahukan tanpa adanya suatu praktek atau gaya belajar yang lainnya.

Manurut Hamalik (2008:57) mengatakan bahwa, "Pembelajaran konvensional adalah suatu kombinasi yang tersusun meliputi unsur-unsur manusiawi, material, fasilitas dan prosedur yang saling mempengaruhi mencapai tujuan pembelajaran". Metode ceramah ini merupakan suatu metode yang banyak digunakan oleh guru sejak dulu, karena metode ini suatu cara penyajian pelajaran yang dilakukan guru dengan penuturan atau penjelasan lisan secara langsung terhadap siswa. 
Menurut Djamarah, dkk (2006:97) mengatakan bahwa, "metode ceramah adalah metode yang boleh dikatakan metode tradisional".

Dengan demikian bahwa metode ceramah itu suatu alat komunikasi lisan antara guru dengan siswa dalam proses belajar mengajar, meskipun metode ceramah ini lebih banyak menuntut keaktifan guru dari pada siswa, tetapi metode ini tidak bisa ditinggalkan begitu saja dalam kegiatan pembelajaran.

Metode ceramah ini dapat dikatakan juga sebagai teknik kuliah, merupakan suatu cara mengajar yang digunakan untuk menyampaikan keterangan atau informasi atau uraian tentang suatu pokok persoalan serta masalah secara lisan.

Menurut Lestari, dkk (2011:167) mengatakan bahwa "metode ceramah adalah suatu cara mengajar yang paling tradisional dan telah lama dilaksanakan oleh para guru".

Metode ceramah ini yang sudah ada sejak dulu, guru sejak dulu kebanyakan menggunakan metode ini mungkin karena kekurangan fasilitas sekolah seperti di pedesaan, oleh karena itu guru hanya bisa menggunakan metode ceramah untuk menyampaikan materi. Metode ini senantiasa bagus bila penggunaannya betul-betul disiapkan dengan baik, didukung alat dan media serta memperhatikan batas-batas kemungkinan penggunaannya.

Langkah-langkah menggunakan metode ceramah ada tiga langkah pokok yang harus diperhatikan, yakni persiapan, pelaksanaan dan kesimpulan. Langkah-langkah tersebut diantaranya adalah :

1. Tahap persiapan

a. Merumuskan tujuan yang ingin dicapai

b. Menentukan pokok-pokok materi yang akan diceramahkan

c. Mempersiapkan alat bantu

2. Tahap pelaksanaan

a. Langkah pembukaan

Langkah pembukaan dalam metode ceramah merupakan langkah yang menentukan.

Keberhasilan pelaksanaan ceramah sangat ditentukan oleh langkah ini.

b. Langkah penyajian

Tahap penyajian merupakan tahap penyampaian materi pembelajara dengan cara berturut. Agar ceramah ini sesuai dengan metode pembelajaran, maka guru harus menjaga perhatian siswa agar tetap terarah pada materi yang sedang disampaikan oleh guru.

c. Tahap mengakhiri atau menutup ceramah

Ceramah harus ditutup dengan ringkasan pokok-pokok mata pelajaran agar materi yang disampaikan oleh guru sudah dipahami atau dikuasai siswa. berikut :

Metode ceramah ini mempunyai beberapa kelebihan dan kekurangannya sebagai

\section{Kelebihan Metode Ceramah}

1. Guru mudah menguasai kelas.

2. Mudah mengorganisasikan tempat/duduk kelas.

3. Dapat diikuti oleh jumlah siswa yang banyak.

4. Mudah mempersiapkan dan melaksanakannya.

5. Guru mudah menerangkan pelajaran dengan baik.

\section{Kelemahan Metode Ceramah}

1. Mudah menjadi verbalisme (pengertian kata-kata). 
2. Yang visual menjadi rugi, yang auditif (mendengar) yang besar menerimanya.

3. Bila selalu digunkan dan terlalu lama, membosankan.

4. Guru menyimpulkan bahwa siswa mengerti dan tertarik pada ceramahnya, ini sukar sekali.

5. Menyebabkan siswa menjadi pasif.

Metode ceramah merupakan suatu cara penyajian pelajaran yang dilakukan guru dengan penuturan atau penjelasan lisan secara langsung terhadap siswa. Dengan kata lain metode ceramah ini siswa dilatih untuk menjadi pendengar yang baik, memahami suatu informasi dan mencatat dengan baik. Tetapi metode ini hanya bisa digunakan untuk mata pelajaran tertentu saja, terkecuali metode ini digunakan secara bersama-sama dengan metode tanya-jawab. Metode ceramah ini biasanya digunakan pada mata pelajaran retorika, karena mata pelajaran retorika itu hanya menuntut siswa agar pandai dalam berbicara di depan kelas, berbeda dengan mata pelajaran akuntansi, karena materi yang disampaikan banyak hitung-hitungannya.

\section{METODE PENELITIAN}

Dalam melakukan penelitian ini, peneliti menggunakan metode eksperimen. Subjek yang diambil dari populasi tertentu yang terbagi menjadi dua kelompok yaitu kelompok eksperimen dan kelompok kontrol.Untuk pengambilan sampel penelitian ini, siswa dan siswi yang tergabung dalam populasi terjangkau diambil dua kelas secara acak yaitu 1 kelas untuk diberi perlakuan pembelajaran Student Teams Achievement Division (STAD)(kelas X BM,A) dan 1 kelas untuk diberi perlakuan pembelajaran Ceramah (kelas X BM.B). yang berjumlah 40 peserta didik yang terdiri dari 20 peserta didik kelompok eksperimen di kelas BM.A yang dibelajarkan dengan pembelajaran kooperatif tipe STAD dan dengan metode konvensional.Adapun desain penelitian yang digambarkan adalah sebagai berikut:

$$
\begin{aligned}
& \mathrm{E}: \mathrm{X}_{1} \rightarrow \mathrm{Y}_{1} \\
& \mathrm{~K}: \mathrm{X}_{2} \rightarrow \mathrm{Y}_{2}
\end{aligned}
$$

\section{Keterangan:}
E : Kelas Eksperimen
K : Kelas Kontrol
$\mathrm{X}_{1}$ : Penggunaan model pembelajaran Student Teams AchievementDivision padakelas eksperimen.
$\mathrm{X}_{2}$ : Penggunaan model pembelajaran Ceramah pada kelas kontrol
$\mathrm{Y}_{1}$ : Hasil belajar akuntansi pada kelas eksperimen
$\mathrm{Y}_{2}$ : Hasil belajar akuntansi pada kelas kontrol 


\section{HASIL PENELITIAN DAN PEMBAHASAN}

Berikut ini di sajikan ringkasan data nilai hasil penelitian berupa hasil perhitungan akhir dari kelas eksperimen dan kelas kontrol. Data tersebut merupakan data yang telah terkumpul dari tes yang telah diberikan kepada peserta didik, berupa tes hasil belajar akuntansi peserta didik yang dolaksanakan setelah proses pembelajaran selesai.

Tabel 4. Perbandingan Hasil Belajar Akuntansi Peserta didik AntaraKelas Eksperimen dan Kontrol

\begin{tabular}{|c|c|c|}
\hline Statistik & Kelas Eksperimen & Kelas Kontrol \\
\hline Skor Nilai Terendah & 62 & 52 \\
\hline Skor Nilai Tertinggi & 100 & 90 \\
\hline Mean & 81,9 & 71,5 \\
Median & 81,5 & 72,3 \\
Modus & 80,17 & 77,5 \\
\hline Simpangan Baku & 9,88 & 10,05 \\
Varians & 97,52 & 101,05 \\
\hline
\end{tabular}

Berdasarkan data perbandingan hasil belajar akuntansi peserta didik antara kelas eksperimen dan kontroldapat terlihat perbandingan statistika deskriptif hasil belajar akuntansipeserta didik antara kelas eksperimen dan kelas kontrol. Dari 20peserta didik kelas eksperimen diperoleh nilai rata-rata $(\bar{X})$ yaitu 81,9 lebih tinggi dibandingkan kelas kontrol yang juga terdiri dari 20peserta didik dengan nilai rata-rata yaitu 71,5. Begitu pula dengan nilai median (Me) sebesar 81,5 serta nilai modus (Mo) sebesar 80,17, pada kelas eksperimen diperoleh nilai lebih tinggi dibandingkan kelas kontrol dengan nilai median (Me) sebesar 72,3 serta nilai modus (Mo) sebesar 77,5.

Kemudian perhitungan dilanjutkan dengan persyaratan analisis data, yaitu uji normalitas dan uji homogenitas. Berikut rekapitulasi hasil uji normalitas dan homogenitas:

Tabel 5. Rekapitulasi Skor Hasil Perhitungan Uji Normalitas

\begin{tabular}{ccccc} 
Kelas & $\begin{array}{c}\text { Jumlah } \\
\text { Sampel }\end{array}$ & Lo & $\begin{array}{c}\text { Ltabel } \\
\alpha=0,05\end{array}$ & Kesimpulan \\
\hline Eksperimen & 20 & 0.1859 & 0,190 & Normal \\
Kontrol & 20 & 0,0629 & 0,190 & Normal \\
\hline
\end{tabular}

Dari hasil perhitungan dalam tabel tersebut, didapat nilai $\mathrm{Lo}=0,1859$ untuk kelas eksperimen dan nilai $\mathrm{Lo}=0,0629$ untuk kelas kontrol, sedangkan dari tabel liliefors untuk $\alpha=0,05$ dan $\mathrm{n}=20$ didapat nilai $\mathrm{L}_{\text {tabel }}=0,190$. Karena nilai $\mathrm{Lo}<\mathrm{L}_{\text {tabel }}$ maka Ho diterima dan disimpulkan "data atau sampel berdistribusi normal". 
Tabel 6. Rekapitulasi Skor Hasil Perhitungan Uji Homogenitas

\begin{tabular}{cccccc} 
Kelompok & $\begin{array}{c}\text { Jumlah } \\
\text { Sampel }\end{array}$ & $\begin{array}{c}\text { Varians } \\
\left(\mathrm{s}^{2}\right)\end{array}$ & $\mathrm{F}_{\text {hitung }}$ & $\mathrm{F}_{\text {tabel }}$ & Kesimpulan \\
\hline Eksperimen & 20 & 97,52 & 1,036 & 2,165 & Terima $\mathrm{H}_{0}$ \\
\hline Kontrol & 20 & 101,05 & & & \\
\hline
\end{tabular}

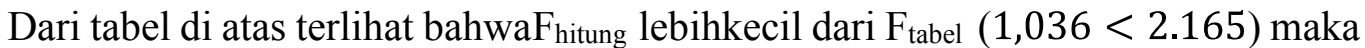
dapat disimpulkan bahwa $\mathrm{H}_{\mathrm{o}}$ diterima sehingga dapat disimpulkan bahwa kedua data memiliki varians yang homogen dengan taraf signifikansi 5\%.

Untuk menguji hipotesis selisih rata-rata antara kelompok 1 dan kelompok 2 menggunakan rumus:

$$
\mathrm{t}=\frac{\overline{\mathrm{X}}_{\mathrm{A}}-\overline{\mathrm{X}}_{\mathrm{B}}}{\mathrm{SD} \sqrt{\frac{1}{\mathrm{n}_{\mathrm{A}}}+\frac{1}{\mathrm{n}_{\mathrm{B}}}}}
$$

$$
S_{\text {gab }} \sqrt{\frac{\left\{\left(n_{A}-1\right) \cdot S_{A}^{2}\right\}+\left\{\left(n_{B}-1\right) \cdot S_{B}^{2}\right\}}{n_{A}+n_{B}-2}}
$$

Sedangkan dari hasil pengujian hipotesis statistik diperoleh statistik data nilai $t_{\text {hitung }}=3,262$ dan $t_{\text {tabel }}=2,025$ pada taraf $5 \%$ yang berarti nilai $t_{\text {hitung }}>$ $\mathrm{t}_{\text {tabel }}(3,262>2,025)$. Hasil tersebut menunjukkan bahwa $\mathrm{H}_{0}$ ditolak dan $\mathrm{H}_{1}$ diterima. Dengan diterimanya $\mathrm{H}_{1}$, hal ini berarti telah membuktikan kebenaran dari hipotesis dengan demikian pemberian model pembelajran Student Teams Achievement Division (STAD) berpengaruh terhadap hasil belajar akuntansi peserta didik.

Dengan demikian rata-rata hasil belajar akuntansi kelompok peserta didik yang diberi model pembelajaran Student Teams Achievement Division (STAD) lebih tinggi dari rata-rata hasil belajar akuntansi kelompok peserta didik yang tidak diberi model pembelajaran Student Teams Achievement Division (STAD) atau dengan kata lain pemberian diberi model pembelajran Student Teams Achievement Division (STAD) mempunyai pengaruh dalam meningkatkan skor hasil belajar akuntansi peserta didik SMK Nasyrul Ulum Pandeglang. Untuk lebih jelasnya dapat dilihat pada tabel di bawah ini"

Tabel 7. Rekapitulasi Hasil Perhitungan Uji Hipotesis

\begin{tabular}{ccccccc} 
Kelompok & Sampel & Mean & Varian & $t_{\text {hitung }}$ & $t_{\text {tabel }}$ & Kesimpulan \\
\hline Eksperimen & 20 & 81,9 & 97,52 & 3,262 & 2,025 & Tolak $H_{0}$ \\
Kontrol & 20 & 71,5 & 101,05 & & & \\
\hline
\end{tabular}

Penelitian ini dilaksanakan di SMK Nasyrul Ulum Pandeglang, pada kelas X dimana para peserta didik ditempatkan di kelas dengan kemampuan yang sama tanpa adanya pengklasifikasian kelas (kelas unggulan dan biasa). Selama proses pembelajaran yang dilakukan dalam penelitian ini, peneliti menggunakan dua kelas. Pada kelas eksperimen proses pembelajaran tentang memproses buku besar dengan pemberian diberi model pembelajaran Student Teams Achievement Division (STAD) sedangkan pada kelas kontrol dengan pemberian diberi model pembelajran Ceramah. 
Berdasarkan hasil penelitian didapat bahwa dengan diberi model pembelajaran Student Teams Achievement Division (STAD) yang diterapkan pada proses pembelajaran dalam penelitian di SMK Nasyrul Ulum Pandeglang memperoleh skor nilai rata-rata lebih tinggi dibandingkan dengan skor nilai rata-rata pemberian diberi model pembelajaran Ceramah.

Hasil penelitian tersebut sejalan dengan penelitian yang pernah dilakukan oleh peneliti lain yaitu Sumardi pada tahun 2009 yang melakukan penelitian "Pengaruh Pembelajaran Kooperatif Tipe Student Teams Achiement Divisions ( STAD ) terhadap Hasil Belajar Matematika" dan Isra Nurmaita pada tahun 2011 yang melakukan penelitian "Efektifitas model belajar Kooperatif Tipe Student Teams Achievement Divisions (STAD) dengan tempat Outdoor Mathematics Terhadap Hasil Belajar Matematika.

Selain itu pemberian model pembelajaran Student Teams Achievement Division (STAD) memberikan dampak positif yaitu peserta didik lebih bersemangat dalam proses pembelajaran dan mampu meningkatkan ketelitiannya, sehingga melatih kesiapan peserta didik dalam menjawab pertanyaan.Dengan model pembelajaranStudent Teams Achievement Division (STAD), memudahkan peserta didik untuk bertukar pikiran antar anggota kelompok sehingga peserta didik lebih percaya diri pada saat menyelesaikan soal, karena peserta didik dapat bertanya (jika kurang mengerti) kepada teman sekelompok mereka tanpa ada rasa malu. Dalam proses pembelajaran ini, guru berperan sebagai fasilitator, memfasilitasi aktivitas belajar siswa dengan menyajikan masalah agar siswa memperoleh pengetahuan barunya dengan penyelidikan dan diskusi.

\section{SIMPULAN}

Berdasarkan hasil penelitian dan pengujian hipotesis dapat disimpulkan bahwa model pembelajaran Student Teams Achievement Division (STAD) berpengaruh terhadap hasil belajar akuntansi peserta didik pada pokok bahasan memproses buku besar kelas X SMK Nasyrul Ulum Pandeglang, Banten.

\section{UCAPAN TERIMA KASIH}

Pada kesempatan yang sangat baik ini, kami mengucapkan puji syukur kepada Allah SWT, yang telah memberikan rahmat dan karuia-Nya kepada kami, serta kami mengucapkan terima kasih kepada peserta didik, para guru, dan terutama kepadaKepala Sekolah Menengah Kejuruan (SMK) Nasyrul Ulum Pandeglang yang telah memberikan izin, serta ucapan terima kasih kepada semua pihakyang telah membantu.

\section{DAFTAR PUSTAKA}

Amaliah, Dini. 2002. Evaluasi Pembelajaran. Jakarta : Unindra Press.

Aunurrahman. 2010. Belajar dan Pembelajaran. Bandung : Alfabeta.

Djamarah, Syaiful Bahri dan Aswan, Zain. 2006. Strategi Belajar Mengajar. Jakarta : Rineka Cipta.

Hamalik, Oemar. 2008. Kurikulum dan Pembelajaran. Jakarta : Bumi Aksara. 
Research and Development Journal Of Education

Vol. 2 No. 1 Oktober 2015

ISSN 2406-9744

Iru, La, dkk. 2012. Analisis Penerapan Pendekatan, Metode, Strategi dan Model-model Pembelajaran. Bantul : Multi Presindo.

Lestari, Sudi, dkk. 2011. Strategi Belajar dan Pembelajaran. Jakarta : Unindra Press.

Trianto. 2011. Model-model Pembelajaran Inovatif Berorientasi Konstruktivistik. Jakarta: Prestasi Pusaka. 